
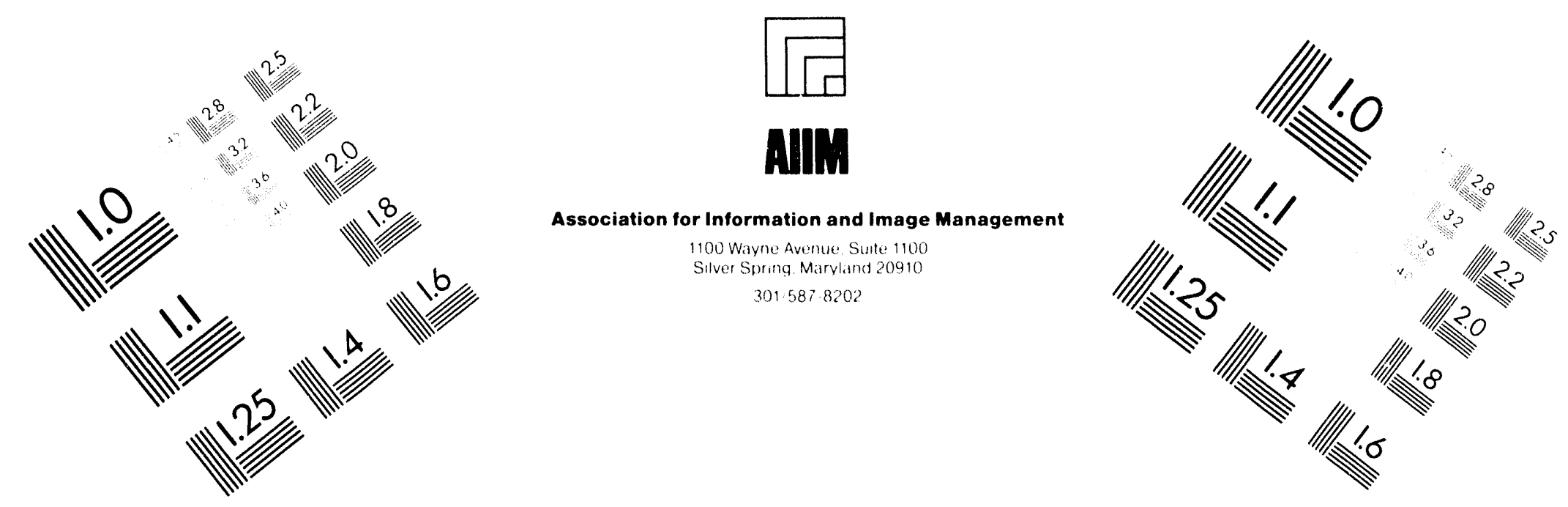

\title{
Centimeter
}

1
$\mid$

Inches
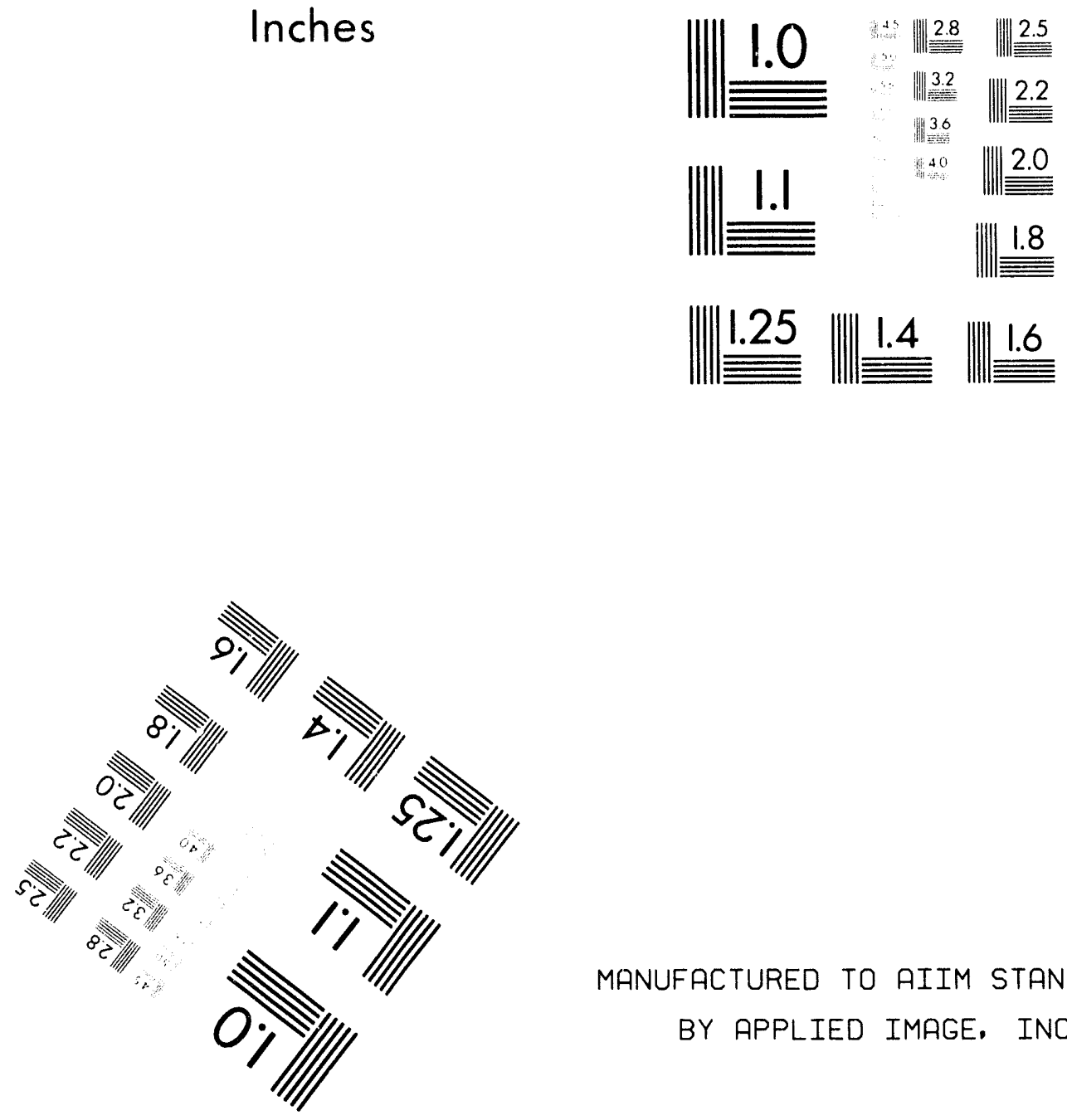

MANUFACTURED TO AIIM STANDARDS

BY APPLIED IMAGE, INC.

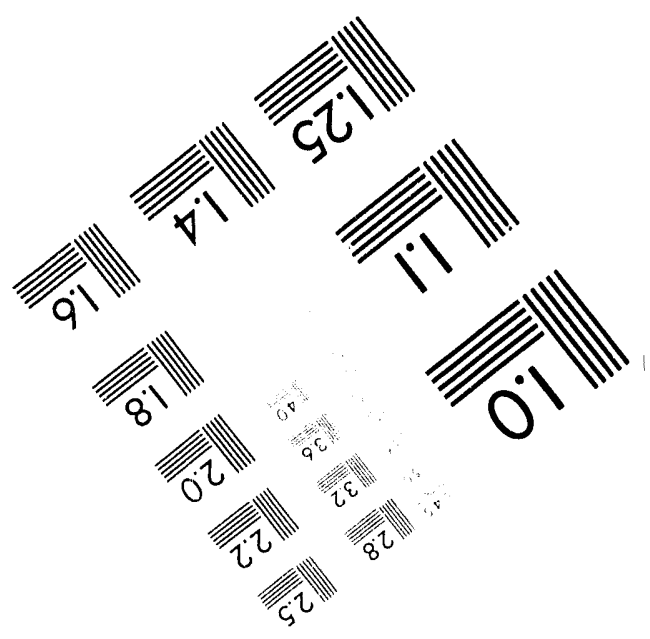



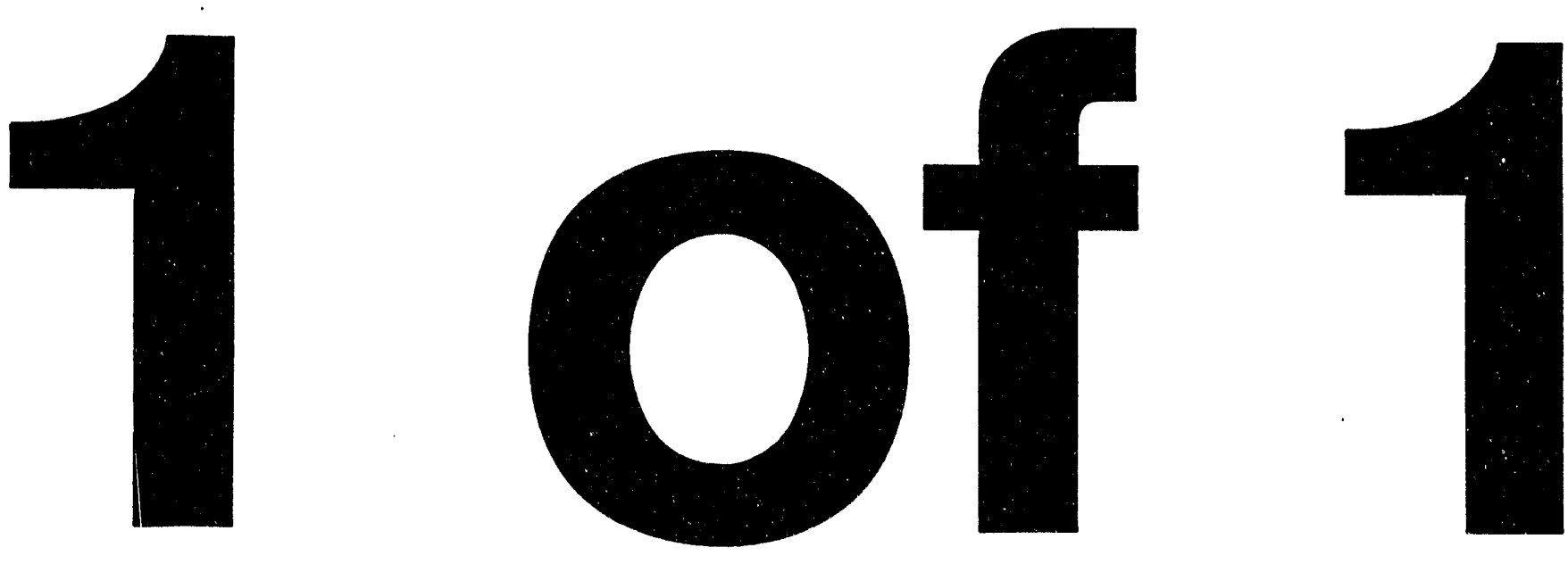


\section{Midwestern High-Level Radioactive Waste Transportation Project}

Cooperative Agreement No. DE-FC01-89CH10402

Document No. DOE/RW/00286-4

FINAL PERFORMANCE REPORT

(Budget Period: February 17, 1989 - December 31, 1993)

\section{Introduction}

On February 17, 1989, the Midwestern Office of The Council of State Governments and the U.S. Department of Energy entered into a cooperative agreement authorizing the initiation of the Midwestern High-Level Radioactive Waste Transportation Project. The transportation project continued to receive funding from DOE through amendments to the original cooperative agreement, with December 31 , 1993, marking the end of the initial 5-year period. This progress report reflects the work completed by the Midwestern Office from February 17, 1989, through December 31, 1993.

\section{Progress Summary}

In accordance with the scopes of work governing the period covered by this report, the Midwestern Office of The Council of State Governments has worked closely with the Midwestern High-Level Radioactive Waste Committee. Project staff have facilitated all eight of the committee's meetings and have represented the committee at meetings of DOE's Transportation Coordination Group (TCG) and Transportation External Coordination Working Group (TEC/WG). Staff have also prepared and submitted comments on DOE activities on behalf of the committee.

In addition to working with the cominittee, project staff have prepared and distributed 20 reports, including some revised reports (see Attachment 1). Staff have also developed a library of reference materials for the benefit of committee members, state officials, and other interested parties. To publicize the library, and to make it more accessible to potential users, project staff have prepared and distributed regular notices of resource availability.

\section{Progress by Task}

\section{Midwestern High-Level Radioactive Waste Committee}

During the period of this report, the Midwestern Office planned and facilitated eight meetings of the Midwestern High-Level Radioactive Waste Committee:

$\begin{array}{lllcc}\text { Location } & \begin{array}{c}\text { Committee } \\ \text { Members in } \\ \text { Attendance }\end{array} & \begin{array}{c}\text { Other } \\ \text { Participants }\end{array} \\ 1 & \text { March 16, 1990 } & \text { Chicago, IL } & 8 & 12 \\ 2 & \text { November 15-16, 1990 } & \text { Minneapolis, MN } & 8 & 18 \\ 3 & \text { May 30-31, 1991 } & \text { Chicago, IL } & 7 & 17 \\ 4 & \text { November 5-6, 1991 } & \text { St. Louis, MO } & 7 & 12 \\ 5 & \text { May 8, 1992 } & \text { Chicago, IL } & 10 & 14 \\ 6 & \text { November 19-20,1992 } & \text { Columbus, OH } & 8 & 17 \\ 7 & \text { May 3-4, 1993 } & \text { South Bend, IN } & 10 & 20 \\ 8 & \text { November 1-2,1993 } & \text { Chicago, IL } & 9 & 15\end{array}$


Each committee meeting has included an update by DOE on activities taking place in the Civilian Radioactive Waste Management Program. In addition, meetings have featured tours of two facilities (GE's Morris storage facility and the Palisades nuclear plant and dry cask storage facility), presentations by the NRC, GAO, DOT, the Commercial Vehicle Safety Alliance, the Edison Electric Institute, and the Nevada Nuclear Waste Project Office, and a risk-communication workshop conducted by the Oak Ridge Institute for Science and Education.

During business sessions, the committee has discussed state activities related to radioactive waste transportation, including actual shipments and emergency response capabilities. The committee has also elected a chairman, commented on meetings of the TCG and the TEC/WG, and passed a resolution on full-scale cask testing.

Project staff representing the committee have regularly attended meetings of the Western Interstate Energy Board's High Level Waste Committee, the Southern States Energy Board's Advisory Committee on Radioactive Waste Transportation, and DOE's TCG and TEC/WG. Staff have also attended occasional meetings of related groups, such as SSEB's TRU Waste Working Group.

On behalf of the committee, staff have prepared and submitted comments on several DOE documents. A complete list of committee-approved correspondence follows:

Description

1 Letter to Thomas H. Isaacs, commenting on OCRWM's Draft Mission Plan Amendment

2 Letter to Pete Bolton, commenting on the possibility of holding a Director's Forum on transportation in conjunction with a TCG meeting

3 Letter to Daniel Metlay, commenting on the draft report of the SEAB Task Force on Radioactive Waste Management

4 Letter to Susan Smith, commenting on the meeting summary from the December 1992 meeting of the TEC/WG

5 Resolution on Full-scale Testing of Spent-fuel Shipping Casks

6 Letter to Secretary Hazel O'Leary, requesting that OCRWM develop a plan for testing full-scale shipping casks (accompanied by Resolution)

7 Letter to Susan Smith, commenting on the July 1993 TEC/WG meeting

8 Letter to Susan Smith, summarizing the issues raised at the November 1993 meeting of the Midwestern High-Level Radioactive Waste Committee

\section{Date}

November 7, 1991

December 14, 1992

February 26, 1993

July 2, 1993

July 15,1993

August 30, 1993

August 30, 1993

December 31, 1993

\section{Midwestern Transportation Primer}

Pursuant to the primer development enhancement plan and annotated outline developed during the first year of this project, the Midwestern Office completed the Midwestern High-Level Radioactive Waste Transportation Primer in May 1991 (DOE/CH/10402-9) and updated the entire document in 1993. In both instances, staff prepared and distributed a draft report for review by the DOE Project Manager, 
committee members, and other parties. The final installment of the updated Primer was in draft form awaiting comment as of December 31, 1993, with the final version scheduled for release in early 1994.

\section{Transportation Handbook}

Project staff prepared a Handbook on High-Level Radioactive Waste Transportation (DOE/CH/10402-19) for state legislative and administrative officials and the general public. The Handbook condensed and updated information contained in the original version of the Midwestern Primer on High-Level Radioactive Waste Transportation Primer. Staff distributed a draft of the report for review and comment by the DOE Project Manager, committee members, and other interested parties. Staff completed the Handbook and distributed it to over 400 people in October 1992. Approximately 200 more copies were distributed to newly elected legislators in June 1993.

\section{Interim Storage Report}

Project staff completed the Report on Interim Storage of Spent Nuclear Fuel (DOE/CH/10402-22), which discussed the technical, regulatory, and economic aspects of spent-fuel storage at nuclear reactors. The report was intended to provide legislators, state officials, and citizens in the Midwest with information on spent-fuel inventories, current and projected additional storage requirements, licensing, storage technologies, and actions taken by various utilities in the Midwest to augment their capacity to store spent nuclear fuel on site. Staff prepared a draft report for review by the DOE Project Manager, committee members, and other interested parties. In May 1993, staff distributed over 100 copies of the report.

\section{Public Participation Study}

In 1993, project staff worked on a draft report on federal, state, and private efforts to include the public in decisions regarding radioactive waste management. Research on the report was ongoing as of December 31, 1993, with a draft report to be circulated for review in early 1994.

\section{Emergency Preparedness and Response}

The Midwestern Office continued to monitor regional developments related to emergency preparedness and emergency response capabilities. Project staff also prepared several reports and advised the DOE Project Manager concerning the need to update these reports.

\section{Title}

1 Midwestern Radiological Emergency Preparedness and Response Agency Report

Revised Report

2 Radioactive Materials Transportation Safety Training Report

3 Report on Mutual Aid Agreements for Radiological Transportation Emergencies

Revised Report

4 Model State Mutual Aid Agreement

5 Timing and Funding of Emergency Response Training in Midwestern States

\author{
Number \\ Date \\ $\mathrm{DOE} / \mathrm{CH} / 10402-2$ \\ May 1990 \\ DOE/CH/10402-2, Rev. 1 July 1993 \\ $\mathrm{DOE} / \mathrm{CH} / 10402-3$ \\ May 1990 \\ $\mathrm{DOE} / \mathrm{CH} / 10402-4$ \\ May 1990
}

DOE/CH/104(12-4, Rev. 1 December 1993

$\mathrm{DOE} / \mathrm{CH} / 10402-5$

December 1990

DOE/CH/10401-14

November 1991 


\section{Transportation Infrastructure}

Project staff prepared and distributed the Highway Infrastr 'cture Report (DOE/CH/10402-16) in February 1992. The report compiled information on state efforts to upgrade the transportation infrastructure in the vicinity of nuclear power reactors in the Midwest. Project staff circulated a draft report for review by state officials in charge of transportation projects.

\section{Routing}

Project staff monitored the status of alternative-route designation in the Midwestern states. In November 1991, staff prepared and distributed the Midwestern States Highway Routing Report (DOE/CH/10401-10), which identified designated alternative routes and state routing authorities. Project staff circulated a draft report for review by the DOE Project Manager, committee members, and other parties.

\section{Public Information}

Project staff developed its public information capabilities to facilitate the exchange of information on transportation-related issues throughout the region. Staff compiled and maintained a reference library on information related to radicactive waste transportation and the federal Civilian Radioactive Waste Management Program. Project staff created and maintained the database storing information on items contained in the library.

To encourage the use of reference materials, staff prepared and distributed a complete index of available resources to committee members, state legislative agencies, the DOE Project Manager, and other parties in December 1990 (DOE/CH/10402-7). Updates of this index were prepared and distributed in May 1991 (DOE/CH/10402-12), November 1991 (DOE/CH/10402-15), May 1992 (DOE/RW/10402-18), November 1992 (DOE/CH/10402-20), May 1993, and November 1993.

To promote awareness of issues related to radioactive waste management, project staff contributed two articles to the Midwestern Legislative Conference's monthly newsletter, Stateline Midwest. In February 1993, staff prepared an article on low-level radioactive waste management. The June 1993 issue included an article on interim storage of spent nuclear fuel.

\section{Transportation Issue Awaremess}

Project staff monitored issues related to radioactive waste transportation, including the activities of the Commercial Vehicle Safety Alliance and the Alliance for Uniform HazMat Transportation Procedures. In addition, staff monitored federal efforts to develop 1) casks for transporting high-level radioactive waste and spent fuel, 2) a facility for the monitored retrievable storage of spent fuel, and 3) a multipurpose canister to use for acceptance, transport, storage, and disposal of spent fuel.

\section{DISCLAIMER}

This report was prepared as an account of work sponsored by an agency of the United States Government. Neither the United States Government nor any agency thereof, nor any of their employees, makes any warranty, express or implied, or assumes any legal liability or responsibility for the accuracy, completeness, or usefulness of any information, apparatus, product, or process disclosed, or represents that its use would not iniringe privately owned rights. Reference herein to any specific commercial product, process, or service by trade name, trademark, manufacturer, or otherwise does not necessarily constitute or imply its endorsement, recommendation, or favoring by the United States Government or any agency thereof. The views and opinions of authors expressed herein do not necessarily state or reflect those of the United States Government or any agency thereof. 


\section{Midwestern High-Level Radioactive Waste Transportation Project}

Cooperative Agreement No. DE-FC02-89CH10402

(Budget Period: February 17, 1989 - December 31, 1993)

\section{PUBLICATIONS}

$\mathrm{DOE} / \mathrm{CH} / 10402-1$

$\mathrm{DOE} / \mathrm{CH} / 10402-2$

$\mathrm{DOE} / \mathrm{CH} / 10402-2$, Rev. 1

$\mathrm{DOE} / \mathrm{CH} / 10402-3$

$\mathrm{DOE} / \mathrm{CH} / 10402-4$

DOE $/ \mathrm{CH} / 10402-4$, Rev. 1

$\mathrm{DOE} / \mathrm{CH} / 10402-5$

$\mathrm{DOE} / \mathrm{CH} / 10402-6$

$\mathrm{DOE} / \mathrm{CH} / 10402-7$

$\mathrm{DOE} / \mathrm{CH} / 10402-9$

$\mathrm{DOE} / \mathrm{CH} / 10402-10$

$\mathrm{DOE} / \mathrm{CH} / 10402-11$

$\mathrm{DOE} / \mathrm{CH} / 10402-12$

$\mathrm{DOE} / \mathrm{CH} / 10402-14$

$\mathrm{DOE} / \mathrm{CH} / 10402-15$

$\mathrm{DOE} / \mathrm{CH} / 10402-16$

$\mathrm{DOE} / \mathrm{RW} / 10402-18$

$\mathrm{DOE} / \mathrm{CH} / 10402-19$

$\mathrm{DOE} / \mathrm{CH} / 10402-20$

$\mathrm{DOE} / \mathrm{CH} / 10402-21$

$\mathrm{DOE} / \mathrm{CH} / 10402-22$
Annual Performance Repurt (Budget Period: 2/17/89-5/31/90)

Midwestern Radiological Emergency Preparedness and Response Agency Report (May 1990; revised July 1993)

Radioactive Materials Transportation Safety Training Report (May 1990)

Report on Mutual Aid Agreements for Radiological Transportation Emergencies (May 1990; revised December 1993)

Model State Mutual Aid Agreement (December 1990)

General Management Plan (Budget Period: 6/1/90-5/31/90)

Index of Available Resources (December 1990)

Midwestern High-Level Radioactive Waste Transportation Primer (May 1991)

Midwestern States Highway Routing Report (November 1991)

Annual Performance Report (Budget Period: 6/1/90-5/31/91)

Index of Available Resources (May 1991)

Timing and Funding of Emergency Response Training in Midwestern States (November 1991)

List of Available Resources (November 1991)

Highway Infrastructure Report (February 1992)

Index of Available Resources (May 1992)

Handbook of High-Level Radioactive Waste Transportation (October 1992)

Index of Available Resources (November 1992)

General Management Plan (Budget Period: 1/1/93-12/31/93)

Report on Interim Storage of Spent Nuclear Fuel (February 1993) 

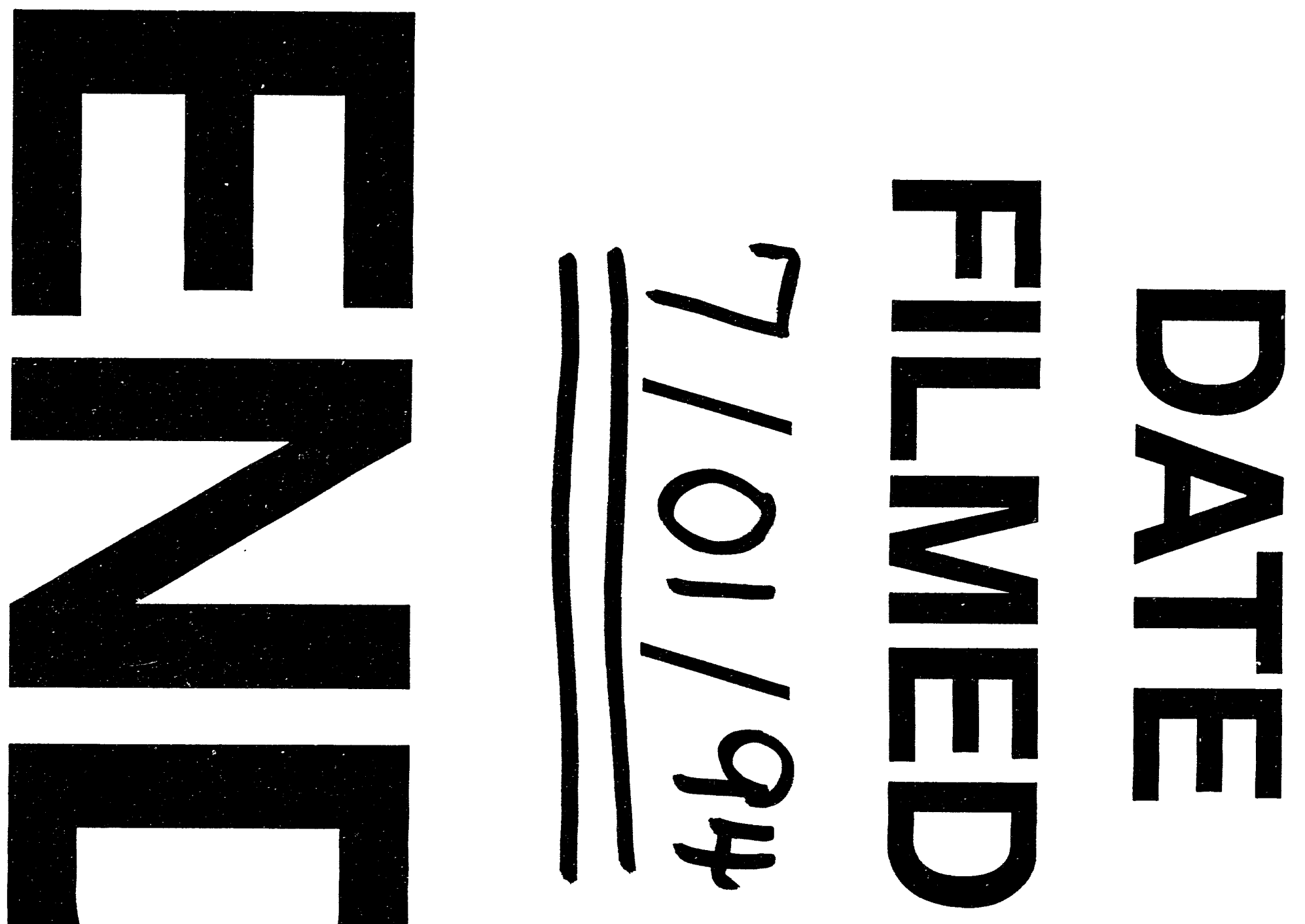
